J. Amer. Soc. Hort. Sci. 115(1):97-101. 1990.

\title{
Mobility Limitations of Bound Polygalacturonase in Isolated Cell Wall from Tomato Pericarp Tissue
}

\author{
James W. Rushing \\ Coastal Research and Education Center, Clemson University, 2865 Savannah Highway, \\ Charleston, SC 29414
}

Donald J. Huber

Vegetable Crops Department, IFAS, University of Florida, Gainesville, FL 32611

Additional index words. Lycopersicon esculentum, pectin, softening, autolysis

\begin{abstract}
Enzymically active cell wall isolated from mature-green and ripening tomato (Lycopersicon esculentum Mill CV. 'Rutgers') fruit was employed to investigate the mobility of the enzyme polygalacturonase (PG, EC 3.2.1.15). Cell walls from mature-green 'Rutgers' fruit or from the ripening mutant rin, which alone exhibits little or no release of pectin, were unaffected by the addition of enzymically active cell wall from ripening 'Rutgers' fruit, indicating that PG is either not transferred at all or is not transferred to sites of pectin hydrolysis. The quantity of pectin released by the addition of soluble PG to enzymically active wall depended on the quantity of enzyme added. Similar data were obtained using purified PG2. Pectin solubilization from all wall isolates exhibiting enzymically mediated pectin release diminished with time; however, transfer to fresh buffer initiated a resumption of autolytic activity, indicating that an inhibitor is released during the course of pectin hydrolysis.
\end{abstract}

Depolymerization of cell wall polyuronides by the endopolygalacturonases (EC 3.2.1.15) is believed to be the dominant feature of softening metabolism in tomato and several other fruit types (Hobson, 1964; Huber, 1983). Purified polygalacturonases (PGs) and crude PG extracts readily hydrolyze pectic polymers in solution and also cause solubilization of uronic acids from isolated cell walls of normal tomato and from the mutant rin (Ali and Brady, 1982; Themmen et al., 1982). Little is known about the action of these enzymes in the wall environment.

In previous work (Rushing and Huber, 1984), we reported on the use of isolated cell wall to investigate details of PGmediated wall hydrolysis in ripening tomato fruit. Evidence of the enzymic nature of cell wall autolysis included the dependency of activity on ripening and the inhibitory and stimulator effects of $\mathrm{Ca}^{++}$and $\mathrm{NaCl}$, respectively, which are known to influence the activity of purified PG (Ali and Brady, 1982; Pressey and Avants, 1982). Additional studies revealed the tenacity of PG binding to isolated cell walls. Treatments with high ionic strength, which have been used to facilitate extraction of PG (Hobson, 1964; Ali and Brady, 1982; Pressey, 1986), did not reduce autolytic activity in wall isolated from ripening tomato fruit (Rushing and Huber, 1987). Other results suggested that PG maybe regulated through the interaction of $\mathrm{pH}$, soluble $\mathrm{Ca}^{++}$, and ionic strength of the apoplast (Rushing and Huber, 1987). These factors may regulate PG activity by affecting the mobility of the enzyme within the cell wall (Rushing and Huber, 1985). In this paper, we report on the use of autolytically active cell wall to investigate the mobility characteristics of PG bound to cell wall.

\section{Materials and Methods}

Plant material. Normal 'Rutgers' tomato and the ripening mutant rin plants were field-grown on stakes and black plastic

Received for publication 28 Nov. 1988. Technical Contribution no. 2871 of the South Carolina Agricultural Experiment Station. We are grateful to Selena Barfield for preparation of this manuscript. The cost of publishing this paper was defrayed in part by the payment of page charges. Under postal regulations, this paper therefore must be hereby marked advertisement solely to indicate this fact. mulch at the Univ. of Florida Horticultural Unit near Gainesville. Fruits were harvested at the mature-green, pink, red (ripe), and overripe developmental stages based on a USDA visual aid for color classification of tomatoes (The John Henry Co., 1975). Fruit were surface-sterilized with $100 \mathrm{ppm} \mathrm{NaOCl}$, rinsed, dried, and sectioned; seed and placental tissue were removed, and the pericarp was stored at $-20 \mathrm{C}$ in sealed polyethylene bags.

Cell wall preparation. Frozen pericarp $(\approx 100 \mathrm{~g})$ was peeled and homogenized in $400 \mathrm{ml}$ of distilled $\mathrm{H}_{2} \mathrm{O}(4 \mathrm{C})$ for $1 \mathrm{~min}$ in a blender set at maximum speed. The homogenate was transferred onto Miracloth and washed with 3 liters of distilled $\mathrm{H}_{2} \mathrm{O}$ (4C) and 1 liter of acetone (1C) with continuous stirring. Cell wall was recovered from the Miracloth and suspended in 100 $\mathrm{ml}$ of cold acetone for $1 \mathrm{hr}$, then filtered through Whatman $\mathrm{GF} / \mathrm{C}$ filters and washed with cold acetone $(\approx 500) \mathrm{ml}$ until pigments were no longer visible. Wall was transferred to a beaker and dried for $24 \mathrm{hr}$ at $30 \mathrm{C}$, with occasional stirring to reduce formation of aggregates. Dry cell wall was stored in sealed containers at $22 \mathrm{C}$ and was used for autolysis experiments within 2 weeks after preparation. For some autolysis experiments, freshly prepared wall was used immediately after removal from the Miracloth without exposure to acetone. All wall preparations were analyzed for total uronic acid content (Ahmed and Labavitch, 1977).

Preparation of PG extract and of purified PG2. About 100 $\mathrm{g}$ of frozen pericarp from peeled, ripe 'Rutgers' tomatoes were added to $100 \mathrm{ml}$ (lC) buffer (50 mm Na-acetate, $\mathrm{pH} 4.5$ ) containing $0.02 \%(\mathrm{w} / \mathrm{v})$ Thimerosal (Sigma, St. Louis). After the addition of $\mathrm{NaCl}$ to a concentration of $1 \mathrm{M}$, the mixture was homogenized for $1 \mathrm{~min}$ in a blender set at maximum speed. The homogenate was held at $1 \mathrm{C}$ for $2 \mathrm{hr}$, then stirred, centrifuged $(10 \mathrm{~min}$ at $7000 \times \mathrm{g})$, and the pellet discarded. The supernatant was adjusted to $80 \%$ saturation with $\left(\mathrm{NH}_{4}\right)_{2} \mathrm{SO}_{4}$, held at $1 \mathrm{C}$ for $24 \mathrm{hr}$, and then centrifuged $(20 \mathrm{~min}$ at $7000 \times \mathrm{g})$. The supernatant was discarded and the pellet was resuspended in $10 \mathrm{ml}$ of buffer (100 mu Na-acetate, $\mathrm{pH} 4.5)$ containing $100 \mathrm{~mm} \mathrm{NaCl}$ and $0.02 \%$ Thimerosal. This solution was dialyzed against 4 liters of the same buffer with three changes during $48 \mathrm{hr}$ at $4 \mathrm{C}$. The final change of bathing buffer was analyzed for the presence of carbohydrate by the phenol-sulfuric assay for total sugar (Dubois et al., 1956). Protein content of the dialyzed extract 
was determined by the method of Bradford (1976). PG2 was isolated and purified using the procedure of Ali and Brady (1982), as modified by DellaPenna et al. (1986).

Autolysis experiments. Cell wall (100 mg dry weight) from pericarp of either mature rin or 'Rutgers' tomatoes at maturegreen, pink, red, or overripe stage of development was placed in a $50-\mathrm{ml}$ centrifuge tube in an ice bath. Wall was dehydrated by dropwise addition of $15 \mathrm{ml}$ of cold (1C) reaction buffer $(50$ $\mathrm{mm} \mathrm{Na}$-acetate, $\mathrm{pH} 4.5$ ) containing $150 \mathrm{~mm} \mathrm{NaCl}$ and $0.02 \%$ Thimerosal. In other experiments, samples were composed of $50 \mathrm{mg}$ of wall from either mature-green 'Rutgers' or rin tissue, along with $50 \mathrm{mg}$ of wall from either pink, red, or overripe 'Rutgers' tissue. After dehydration with buffer, samples were held at $1 \mathrm{C}$ for 30 rein, with occasional stirring, then centrifuged $(10 \mathrm{~min}$ at $7000 \times \mathrm{g})$ using a Beckman Model J2-21 centrifuge equipped with a JA-20 rotor. The supernatant was filtered through Whatman GF/C filters to obtain a time-zero sample and the wall was resuspended in $15 \mathrm{ml}$ of fresh reaction buffer. Reaction mixtures were incubated in a shaking bath at 34C. Centrifugation, supernatant removal, and pellet resuspension steps were repeated at selected intervals during incubation. All supernatants were analyzed for total uronic acids (Blumenkrantz and AsboeHansen, 1973) and uronic acid-reducing sugars (Milner and Avigad, 1967). After the $7 \mathrm{hr}$ of incubation, filtered wall was suspended in $30 \mathrm{ml}$ of acetone, filtered through tared Whatman $\mathrm{GF} / \mathrm{C}$ filter paper, and dry weights obtained after storage for 48 $\mathrm{hr}$ in a desiccator in vacuo.

Other autolysis studies used freshly extracted, hydrated wall from tissues of the same stages of development as described above. Autolysis experiments employing various mixtures of cell wall preparations were also performed. Since preautolysis dry weights were not obtainable, walls were dispensed by volume using a spatula. After transferring walls to centrifuge tubes, the total volume was adjusted to $15 \mathrm{ml}$ with reaction buffer. All subsequent steps were as described for experiments with dry cell wall preparations. Postautolysis dry weights were added to the weight ( $\mu \mathrm{g}$ uronic acid equivalents) of solubilized uronic acids to obtain an estimate of the preautolysis wall dry weight.

In an additional autolysis study using dried cell wall, two methods for sampling soluble products were compared for their effect on release of polyuronides from walls of either maturegreen or red 'Rutgers' pericarp. The first sampling method was as described earlier (i.e., centrifugation and supernatant removal), after which walls were provided with fresh reaction buffer. This method was compared to that of removing an aliquot $(0.5 \mathrm{ml}$ of buffer $)$ from the reaction mixture at intervals throughout the experiment. Aliquots were filtered through Whatman GF/C filter papers and analyzed for total uronic acids and uronic acid-reducing groups. Postautolysis recovery of cell wall was performed as described previously.

$P G$ activity in supernatants from autolytic reations. Supernatants were recovered by filtration from autolysis reaction mixtures in which cell wall from either pink or red pericarp had been incubated. To $6 \mathrm{ml}$ of the supernatant were added either $50 \mathrm{mg}$ of wall isolated from mature-green pericarp or $12 \mathrm{mg}$ polygalacturonic acid (Sigma). Boiled supernatant controls were included. An aliquot $(0.5 \mathrm{ml})$ was taken immediately for assay of acid-reducing sugars (Milner and Avigad, 1967), and additional aliquots were removed after 4 and $12 \mathrm{hr}$ incubation at $34 \mathrm{C}$ in a shaking water bath.

Cell wall treated with multiple additions of $P G$. Autolytically inactive cell walls (100 mg dry weight) from 'Rutgers' maturegreen tomatoes were suspended in $15 \mathrm{ml}$ of cold buffer $(50 \mathrm{~mm}$
Na-acetate, $\mathrm{pH} 4.5$ ) containing $150 \mathrm{~mm} \mathrm{NaCl}$ and $0.02 \%(\mathrm{w} / \mathrm{v})$ Thimerosal. To the suspension was added $200 \mu \mathrm{l}$ of either active or boiled enzyme ( $\approx 75 \mu \mathrm{g}$ protein), or buffer alone. Reaction mixtures were incubated at $34 \mathrm{C}$ in a shaking water bath. Initially, and at selected intervals, aliquots $(0.5 \mathrm{ml})$ were removed, filtered through Whatman GF/C filters, and analyzed for uronic acid content. When the rate of polyuronide solubilization had declined to near zero, reaction mixture volumes were readjusted to $15 \mathrm{ml}$ with fresh buffer and the enzyme addition repeated. A total of four aliquots of enzyme were added during the $32 \mathrm{hr}$ of incubation. Cell wall recovery for dry weight determination was performed as described for autolysis experiments.

Similar experiments were performed using purified PG2. Cell walls $(25 \mathrm{mg})$ from mature-green tomato fruit were dehydrated by addition of $7.5 \mathrm{ml}$ cold buffer ( $50 \mathrm{~mm} \mathrm{Na}$-acetate) containing $150 \mathrm{~mm} \mathrm{NaCl}$ and $0.02 \%$ (w/v) Thimerosal. To the suspension was added $200 \mu \mathrm{l}$ of the PG2 preparation ( $\approx i 8 \mu \mathrm{g}$ protein). Other details were as described above.

In other experiments, cell wall was exposed to high $\mathrm{pH}$ to demethylate pectins before addition of PG (Babbit et al., 1973). Wall was dehydrated in $15 \mathrm{ml}$ of buffer $\left(50 \mathrm{~mm} \mathrm{NaHCO}{ }_{3}-\mathrm{NaOH}\right.$, $\mathrm{pH} 11.0$ ) and allowed to stand for $30 \mathrm{~min}$ at 20C. After this exposure to high $\mathrm{pH}$, samples were adjusted to $80 \%$ acetone (v/ v) to precipitate the cell wall, then centrifuged $(10 \mathrm{~min}$ at $7000 \times$ g). The supernatant was removed, and the cell wall was washed once with $20 \mathrm{ml}$ of reaction buffer, and then resuspended in 15 $\mathrm{ml}$ of reaction buffer. An aliquot of enzyme was added and the procedure was performed as described above, except that the incubation time was reduced to $10 \mathrm{hr}$.

In another multiple addition experiment, either active or boiled PG was added to autolytically inactive cell was as described. When the rate of polyuronide solubilization declined to near zero, the reaction mixture was centrifuged $(10 \mathrm{~min}$ at $7000 \times$ $\mathrm{g}$ ), the supernatant removed, and the wall provided with $15 \mathrm{ml}$ of fresh buffer. No additional PG was added to the mixture, allowing us to determine whether further polyuronide solubilization would occur in the absence of additional enzyme.

\section{Results}

Autolysis experiments. Polyuronides were released from enzymically active cell wall (Fig. 1) at rates comparable to those observed in earlier studies, in which autolytic activity was first noted in wall from fruit at the onset of ripening and increased as ripening proceeded, then decreased slightly during senescence (Rushing and Huber, 1984). The only exception here is that uronic acid solubilization from wall of pink fruit was considerably lower here than in previous work. Reaction mixtures composed of cell wall from rin tissue along with enzymically active walls from 'Rutgers' pink, ripe, or over-ripe pericarp released quantities of uronic acids equal to the yield expected from the enzymically active wall (Fig. 1). Similar results were obtained when rin cell wall was used in place of wall from 'Rutgers' mature-green fruit (data not shown). In experiments using freshly prepared, hydrated cell wall, results were identical to those obtained with cell wall that had been dried following isolation (data not shown). In all experiments reported here, exposure of cell wall to boiling $80 \% \mathrm{EtOH}$ before incubation at $34 \mathrm{C}$ reduced autolytic activity to near zero, regardless of developmental stage of the tissue from which walls were isolated (data not shown).

Periodically transferring autolytically active wall to fresh buffer was found to have a dramatic effect on the quantity of polyuronides released. When cell wall was maintained in the initial 


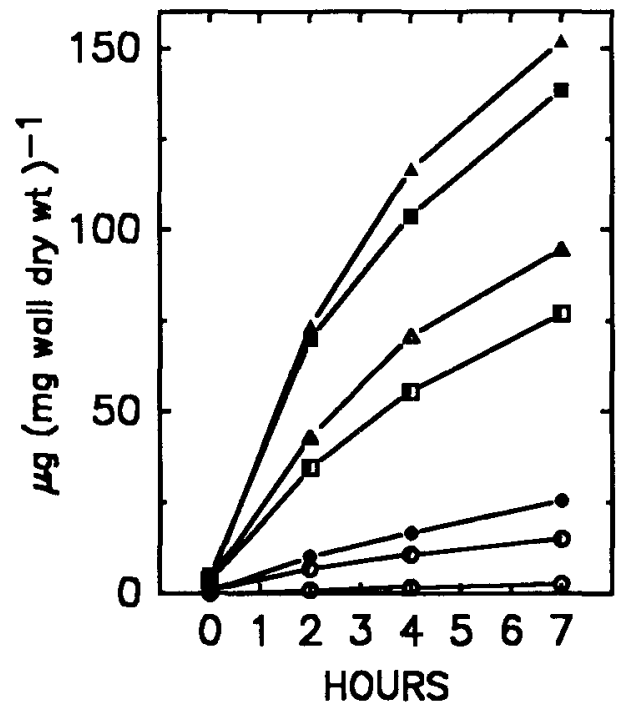

Fig. 1. Release of polyuronide from cell walls isolated from pericarp

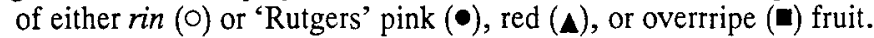
Wall was incubated at $34 \mathrm{C}$ in Na-acetate buffer $(50 \mathrm{mM}, \mathrm{pH} 4.5)$ containing $150 \mathrm{~mm} \mathrm{NaCl}$ and $0.02 \%$ Thimerosal. Half-closed symbols represent mixtures of equal quantities of walls from rin and either pink (⿻), red $(\Delta)$, or overripe ( $\boldsymbol{D})$ 'Rutgers'. Results are from a single experiment with duplicate samples and SE are smaller than the symbols. The experiment was repeated twice with similar results.

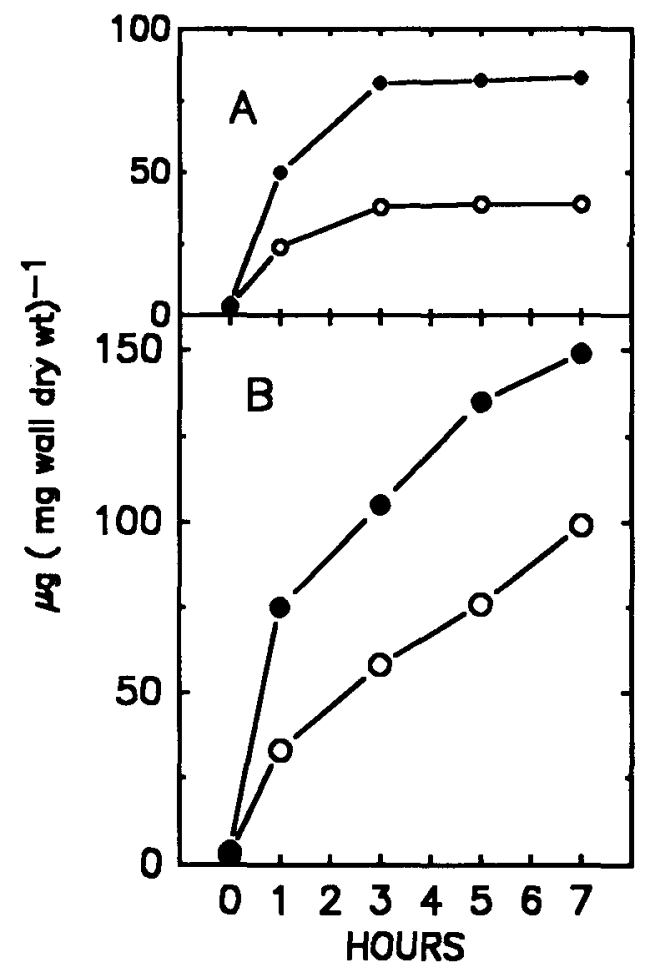

Fig. 2. Autolytic activity in wall incubated under static conditions or periodically transferred to fresh buffer. Results are from a single experiment with triplicate cell wall samples. Bars represent SE and, when absent, are smaller than the symbols. The experiment was repeated twice, with similar results each time. (A) Buffer unchanged. (B) Buffer replaced at each sampling. (•) Total uronic acid. (O) Uronic acid reducing groups.

buffer, the rate of release declined to near zero after $3 \mathrm{hr}$ incubation, at which time $\approx \$ 80 \mu \mathrm{g}$ uronic acid/mg of cell wall had been solubilized (Fig. 2). In contrast, reaction mixtures that were resuspended in fresh buffer at each measurement released $>100 \mu \mathrm{g}$ polyuronide/mg of wall dry weight during the first 3 $\mathrm{hr}$, and continued to release uronic acids throughout incubation (Fig. 2). Wall periodically provided with fresh buffer during 7 hr released nearly $150 \mu \mathrm{g}$ uronic acid/mg of wall dry weight, almost a $95 \%$ increase over the amount released when fresh buffer was not provided. Cell wall from mature-green tissue did not release acid sugars during incubation, regardless of buffer conditions (data not shown).

$P G$ activity in supernatants from autolytic reactions. Protein amounting to $\approx 16 \%$ of the initial wall dry weight was released from wall of both pink and red pericarp during autolysis at $\mathrm{pH}$ 4.5. Boiled controls released $<1 \%$ of the initial weight (data not shown). Pressey (1986) reported that PG is not effectively extracted from tomato pericarp at this $\mathrm{pH}$; however, we observed the release of protein from our enzymically active wall. The protein apparently did not contain more than a trace of PG activity; i.e., it did not cause the solubilization of uronic acid sugar-reducing groups when autolysis supernatants were mixed with polygalacturonic acid or with wall isolated from maturegreen pericarp (data not shown).

Cell wall treated with multiple additions of $P G$. Each addition of the unpurified PG preparation $(\approx 75 \mu \mathrm{g}$ ) to the reaction mixture resulted in the solubilization of $\approx 10 \mu \mathrm{g}$ uronic acid $/ \mathrm{mg}$ of wall dry wt (Fig. 3). The rate of release declined to near zero within $2 \mathrm{hr}$ after each addition of active enzyme (Fig. 3). Boiled enzyme did not cause release of polyuronides (Fig. 3), nor did buffer alone (data not shown). Pretreating wall in $\mathrm{pH} 11.0$ buffer before addition of enzyme did not influence the rate or extent of polyuronide solubilization compared to wall with no such exposure (Fig. 4).

As in the autolytic reactions, replacing the buffer caused further release of polyuronide in the absence of additional enzyme in quantities that amounted to $\approx 60 \%$ of those released by the initial aliquot of enzyme (Fig. 5). In contrast, walls that were centrifuged but resuspended in the same buffer did not release additional uronic acids (Fig. 5).

Figure 6 illustrates that the kinetics of pectin release exhibited by the crude PG preparation were also observed with purified

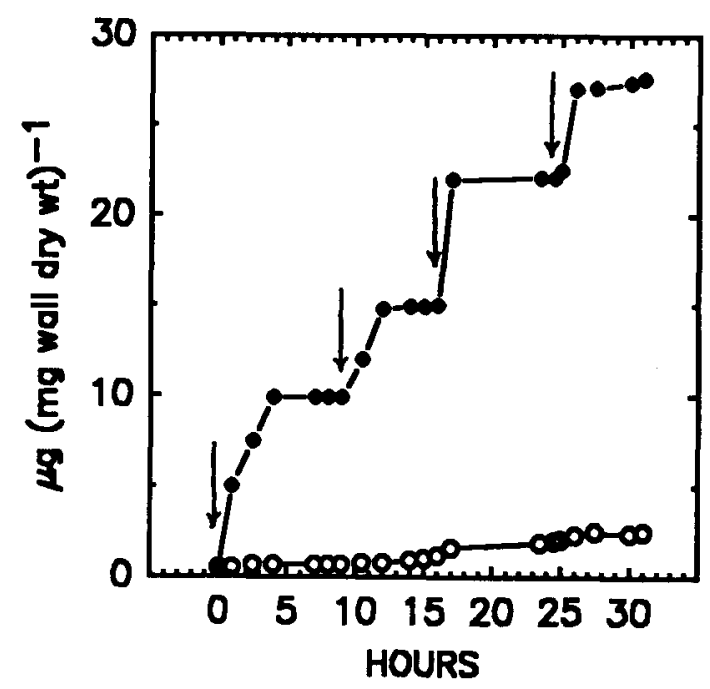

Fig. 3. Solubilization of uronic acid from cell walls isolated from 'Rutgers' mature-green pericarp by a polygalacturonase extract. Arrows indicate addition of either active $(\bullet)$ or boiled $(0)$ enzyme. Results are from a single experiment with triplicate cell wall samples. Experiment was repeated twice, with similar results each time. 


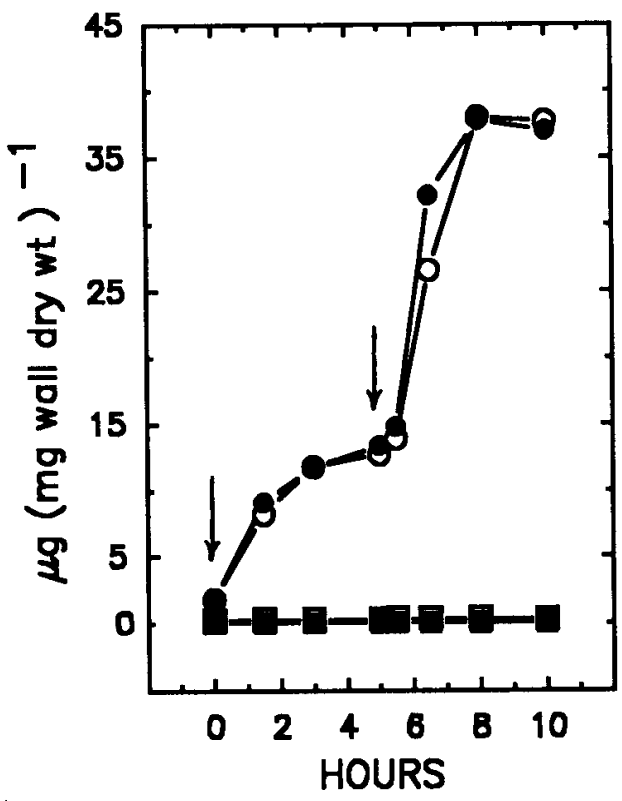

Fig. 4. Solubilization of uronic acid from cell walls isolated from 'Rutgers' mature-green pericarp and pretreated at either $\mathrm{pH} 4.5(\bullet$, -) or $\mathrm{pH} 11.0(0, \square)$ Arrows indicate addition of either active ( $\bullet$, o) or boiled $(\square, \square)$ polygalacturonase extract. Experimental design was as described in Fig. 3.

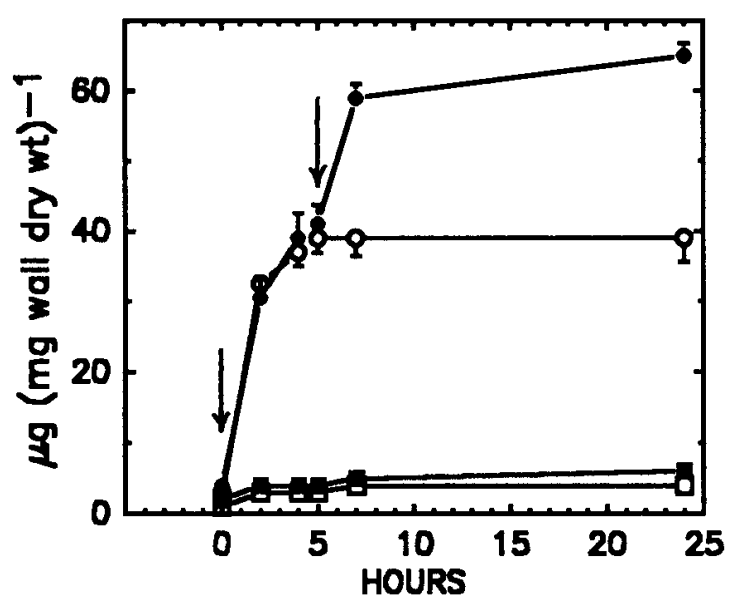

Fig. 5. Solubilization of polyuronides from cell walls isolated from 'Rutgers' mature-green pericarp by a polygalacturonase extract. Arrow indicates point at which some samples $(\bullet, \mathbf{E})$ were transferred to fresh buffer. Other wall samples $(O, \square)$ were resuspended in the initial buffer. Symbols indicate the use of either active $(\bullet, 0)$ or boiled $(\boldsymbol{\square}, \square)$ enzyme.

polygalacturonase (PG2). Since cell wall was not treated to inactivate-bound enzymes, the possibility remains that even the purified enzyme was acting in concert with other proteins.

\section{Discussion}

The tenacity of binding of PG to cell wall is exemplified by the fact that high concentrations of ionic strength are required to effect removal of the enzyme (Pressey, 1986). Heterogeneity of binding is also indicated by the observation that wall subjected to high concentrations of salt shows little alteration in the quantitative features of cell wall autolysis (Rushing and Huber, 1987).

On the basis of the inability of high salt and other agents to achieve complete removal of wall-associated enzymes, some

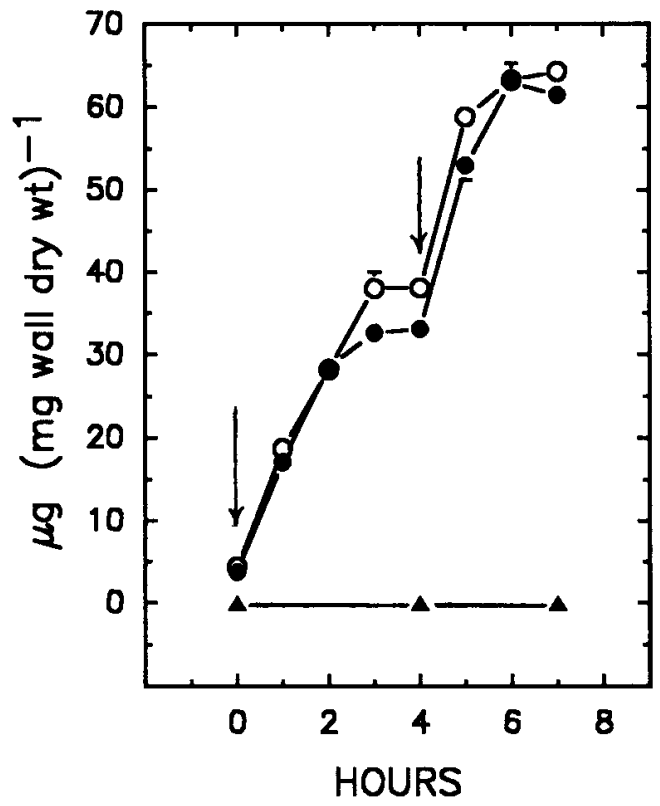

Fig. 6. Solubilization of polyuronides from cell walls isolated from 'Rutgers' mature-green pericarp by purified polygalacturonase (PG2). Arrow indicates point at which additional PG2 was added. Symbols $(\bullet, 0)$ represent two separate experiments with active PGII with triplicate wall samples in each experiment. (A) Boiled enzyme controls. SE bars, when absent, are smaller than the symbols.

workers have suggested that, for bacterial autolytic enzymes (Brown et al., 1970; Shockman et al., 1967) and for plant invertases (Parr and Edelman, 1975) and peroxidases (Dashek et al., 1979), a proportion of the enzyme population is covalently bound. Although there is no direct evidence for covalent association, it is quite clear that the binding between the proteins of both endogenous and foreign origin and cell wall is quite strong (Jansen et al., 1960; Nagahashi, 1987). Strong ionic interactions are often implicated, but steric occlusion, lectin interactions, or binding to substrates may also be involved. The tenacity of binding of PG to cell wall raises interesting questions regarding the manner by which PG functions in autolytic reactions. Within the duration of the autolytic experiments reported here, only trace quantities of PG activity were detected in the bathing solution, although considerable protein was present. We did not investigate the possibility that this protein might represent, in part, inactivated PG. Additional evidence for the failure of cell wall to yield significant quantities of active PG during autolytic reactions was the observation that $\mathrm{PG}$ was not transferred in reactions employing mixtures of active and inactive wall. This fact, in addition to the dependency of autolytic yields on the quantity of bound PG (Rushing and Huber, 1984), indicated that individual PG molecules function within a limited microenvironment. The failure of cell wall to release PG during autolytic reactions may seem expected, in view of reports that PG is not released from cell wall at $\mathrm{pH} 4.5$ (Pressey, 1986). It must be borne in mind that in the latter study, extractions were performed under low temperature. Thus, these data do not address the question of whether PG is released under conditions of autolysis.

Inhibitors accumulating in the incubation buffer may be an important factor in this phenomenon, since providing fresh buffer significantly increased the quantity of uronic acids released during autolysis (Fig. 2). Evidence that the inhibitor may be solubilized by PG action is found in the results of the multiple- 
addition experiments. The capacity of added PG to solubilize cell wall uronic acids was, in time, diminished; however, transferring the cell wall to fresh buffer caused a resumption of polyuronide solubilization without the addition of more enzyme (Fig. 5). This result indicates that, in a closed static system, individual PG molecules have a limited hydrolytic capacity. If one assumes that the inhibitor is released from the wall by PG action, there are numerous possibilities. Products released as a consequence of pectin hydrolysis in cell wall include uronic acid (Hobson, 1964), calcium (Rigney and Wills, 1981), neutral sugars (Gross and Wanner, 1979; Huber, 1983; Gross and Sams, 1984), protein (Hobson et al., 1983), and possibly other unidentified components of the cell wall. Calcium exhibits the characteristics capable of causing the observed suppression of autolysis in a static system. Calcium could explain the decrease in hydrolytic capacity via its ability to rigidify polymeric pectin and consequently restrict the capacity of PG to migrate within the wall. The addition of exogenous calcium has been shown to greatly diminish autolytic activity (Rushing and Huber, 1987). The reversibility of the inhibition is also consistent with a role for calcium.

Alkaline desterification of wall pectin did not appear to influence the extent of pectin hydrolysis in isolated cell wall. It is possible, however, that the cell wall preparations contained bound pectin methylesterase (PME, EC 3.1.1.11), which, if functioning under the reaction conditions, would serve to enzymically demethylate pectin. Seymour et al. (1987) demonstrated a promotive effect of PME on PG-mediated wall hydrolysis.

A final point worth noting is the variability observed in the amount of uronic acid released from cell wall from pink pericarp compared to the yields from walls of tissues at other stages of development (Rushing and Huber, 1984; Fig. 1). Pink tomatoes are not uniformly pink, but are composed of zones of green and light-red tissues (The John Henry Co., 1975). When selecting samples of pericarp for cell wall extraction, it is difficult to ensure that each sample is composed of the same proportion of the chronologically distinct tissue types. Since PG apparently does not move freely through mixtures of cell wall from different developmental stages in vitro (Fig. 1), considerable variability could result from using pink tissue. The consistency observed in autolytic yields from red fruit is probably due to a moreuniform distribution of PG within the pericarp tissue. We conclude from these data that the binding and mobility characteristics of PG are of considerable importance in regulating pectin hydrolysis in isolated cell wall and, possibly, in vivo. The inhibition observed in autolysis reactions performed under static conditions may in fact be more accentuated in vivo, particularly if the soluble inhibitor remains sequestered in the apoplast. This situation would explain why pectin hydrolysis in vitro is of a significantly greater magnitude than that occurring in vivo.

\section{Literature Cited}

Ahmed, A.E. and J.M. Labavitch. 1977. A simplified method for accurate determination of cell wall uronide content. J. Food Biochem. $1: 361-365$.

Ali, Z.M. and C.J. Brady. 1982. Purification and characterization of the polygalacturonases of tomato fruits. Austral, J. Plant Physiol. 9:155-169.

Babbit, J.K., M.J. Powers, and M.E. Patterson. 1973. Effects of growth regulators on cellulase, polygalacturonase, respiration, color, and texture of ripening tomatoes. J. Amer. Soc. Hort. Sci. 98:7781 .
Blumenkrantz, N. and G. Asboe-Hansen. 1973. New method for quantitive determination of uronic acids. Anal. Biochem. 72:484-489.

Bradford, M, 1976. A rapid and sensitive method for the quantitation of microgram quantities of protein utilizing the principle of proteindye binding. Anal. Biochem. 72:248-254.

Brown, W., C.D. Fraser, and F.E. Young. 1970. Problems in purification of a Bacillus subtilis autolytic enzyme caused by association with teichoic acid. Biochem. Biophys. Acts 198:308-315.

Dashek, W.V., S.S. Erickson, D.M. Hayward, G. Lindbeck, and R.R. Mills. 1979. Peroxidase in cytoplasm and cell wall of germinating lily pollen. Bot. Gaz. 140:261-265.

DellaPenna, D., D.C. Alexander, and A.B. Bennett. 1986. Molecular cloning of tomato fruit polygalacturonase: Analysis of polygalacturonase mRNA levels during ripening. Proc. Natl. Acad. Sci. USA 83:6420-6424.

Dubois, M., R.A. Gilles, J.K. Hamilton, P.A. Rebers, and R. Smith. 1956. Calorimetric method for determination of sugars and related substances. Anal. Chem. 28:350-356.

Gross, K.C. and C.E. Sams. 1984. Changes in cell wall neutral sugar composition during fruit ripening: A species survey. Phytochemistry 23:2457-2461.

Gross, K.C. and S.J. Waller. 1979. Degradation of cell wall polysaccharides during tomato fruit ripening. Plant Physiol. 63: 117-120.

Hobson, G.E., C. Richardson, and D.J. Gillham. 1983. Release of protein from normal and mutant tomato cell walls. Plant Physiol. 71:635-638.

Hobson, G.E. 1964. Polygalacturonase in normal and abnormal tomato fruit. Biochem. J. 92:324-332.

Huber, D.J. 1983. The role of cell wall hydrolyses in fruit softening. Hort. Rev. 5:169-219.

Jansen, E.F., R. Jang, and J. Bonner. 1960. Binding of enzymes to Avena coleoptile cell walls. Plant Physiol. 35:567-574.

Milner, Y. and G. Avigad. 1967. A copper reagent for the determination of hexuronic acids and certain ketohexoses. Carbohydr. Res. 4:359-361.

Nagahashi, G. 1987. Binding-dissociation properties of cell wall enzymes. Plant Physiol. S-83:106.

Parr, D.R. and J. Edelman. 1975. Release of hydrolytic enzymes from the cell walls of intact and disrupted carrot callus tissue, Planta 127:111-119.

Pressey, R. 1986. Extraction and assay of tomato polygalacturonases. HortScience 21:490-492.

Pressey, R. and J.K. Avants. 1982. Solubilization of cell walls by tomato polygalacturonases: Effects of pectinesterases. J. Food Biochem. 6:57-74.

Rigney, C.J. and R.B.H. Wills. 1981. Calcium movement, a regulating factor in the initiation of tomato fruit ripening. HortScience 16:550-551.

Rushing, J.W. and D.J. Huber. 1984. In vitro characterization of tomato fruit softening: The use of enzymically active cell walls. Plant Physiol. 75:891-894.

Rushing, J.W. and D.J. Huber. 1985. Mobility of polygalacturonase in isolated cell wall. Plant Physiol. S-77:66.

Rushing, J.W. and D.J. Huber. 1987. Effects of $\mathrm{NaCl}$, $\mathrm{pH}$ and $\mathrm{Ca}^{++}$ on autolysis of isolated tomato fruit cell walls. Physiol. Plant. 70:7884.

Seymour, G. B., Y. Lasslett, and G.A. Tucker. 1987. Differential effects of pectolytic enzymes on tomato polyuronides in vivo and in vitro. Photochemistry 26:3137-3139.

Shockman, G.D., J.S. Thompson, and M.J. Conover. 1967. The autolytic enzyme system of Streptococcus faecalis. II. Partial characterization of the autolysin and its substrate. Biochemistry 6:10541065 .

The John Henry Co. 1975. Color classification requirements in tomatoes. USDA Visual Aid TM-L-1. The John Henry Co., Lansing, Mich.

Themmen, A.P.N., G.A. Tucker, and D. Grierson. 1982. Degradation of isolated tomato cell walls by purified polygalacturonase in vitro. Plant. Physiol. 69:122-124. 